\title{
Experimental detection of antioxidant and atherogenic effects of grapes seeds extracts in rabbits
}

\author{
Sh.A. Al-Bajari ${ }^{1}$, M.A. Al- Akash ${ }^{1^{*}}$ and H.Kh. Ismail ${ }^{2}$ \\ ${ }^{1}$ Department of Medical Laboratory Techniques, Technical Institute Mosul, Northern Technical University, \\ ${ }^{2}$ Department of Pathology and Poultry Diseases, College of Veterinary Medicine University of Mosul, Mosul, Iraq \\ "email: moatazakash78@gmail.com
}

(Received June 30, 2018; Accepted September 14, 2018)

\begin{abstract}
The aim of this study was to determine the ability of Grapes seeds (Vitis vinifera) aqueous, proteinous, non- proteinous and alcoholic extracts as antioxidant and antiatherogenic in rabbits after exposure to $0.5 \% \mathrm{H}_{2} \mathrm{O}_{2}$ in drinking water for 30 days. The results illustrated capability of $0.5 \% \mathrm{H}_{2} \mathrm{O}_{2}$ to initiate oxidative stress via significant decrease in Glutathione (GSH), glutathione peroxdiase (GPx), Catalase (CAT) and superoxide dismutase (SOD) level in heart and liver concomitant with significant increase in malondialhyde (MDA) in addition to decrease in high density lipoprotein- cholesterol (HDL-c) and increase low density lipoprotein- cholesterol (LDL-c) in serum of treated only with $\mathrm{H}_{2} \mathrm{O}_{2}$ rabbits. While rabbits treated with $\mathrm{H}_{2} \mathrm{O}_{2}$ associated with Grapes seeds (aqueous, proteinous, non- proteinous and alcohol) extracts for 15 days showed a significant increase of Glutathione (GSH), glutathione peroxdiase (GPx), superoxide dismutase (SOD) concentration in the heart and liver tissue as well as increase HDL-c, decrease in LDL-c and VLDL-c. While, the histolopathological examination of heart and liver tissue demonstrated that $\mathrm{H}_{2} \mathrm{O}_{2}$ induces, degeneration, necrosis and few inflammation foci in the liver and myocardial muscle. While the administration of (Vitis vinifera) aqueous, proteinous, non-proteinous and alcoholic extracts cause improvement in the histological picture of the liver and the myocardial muscle. It was concluded that the (Grapes extracts) aqueous, proteinous, non-proteinous and especially the alcoholic extracts can reduce the damage caused by $\mathrm{H}_{2} \mathrm{O}_{2}$ and this will pave the way to investigate the protective effects of the natural substances in the diseases caused by oxidative stress.
\end{abstract}

Keywords: Grapes seeds, Lipid peroxidation, Antioxidants, Oxidative stress

Available online at http://www.vetmedmosul.com

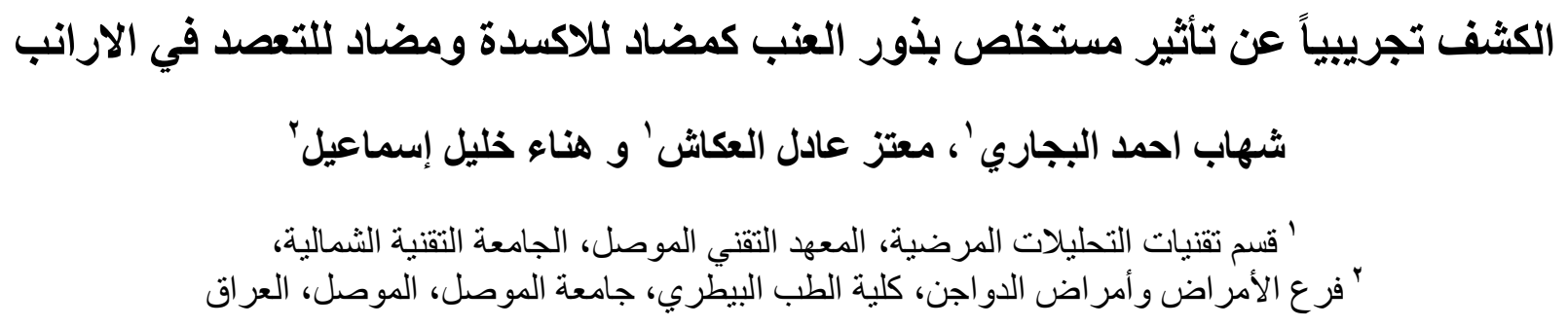

الخلاصة

تضمن البحث دراسة قابلية بذور العنب Vitis vinifera بشكل مستخلص مائي أو مركبات بروتينية أو مركبات غير بروتينية أو

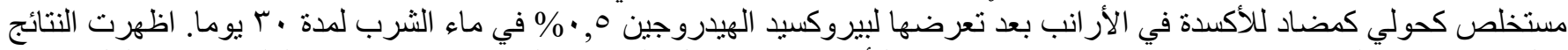

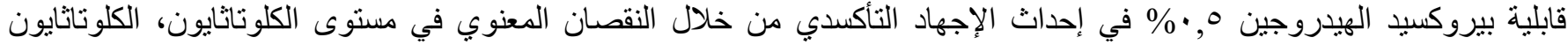

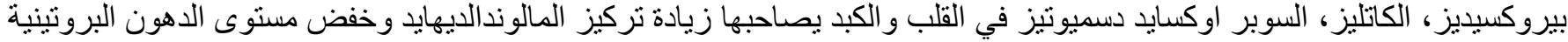

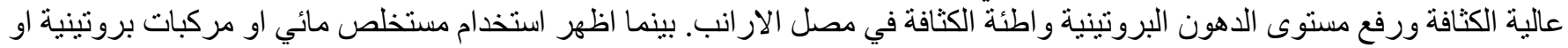

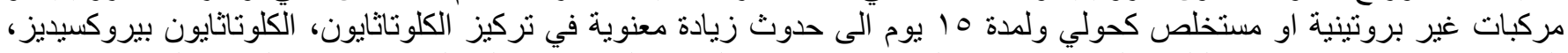
السوبر اوكسايد دسميوتيز في القلب و الكبد فضلا عن الزيادة في مستوى الدهون البروتينية عالية الكثافة وخفض الدئية الدهون البروتينية واطئة 


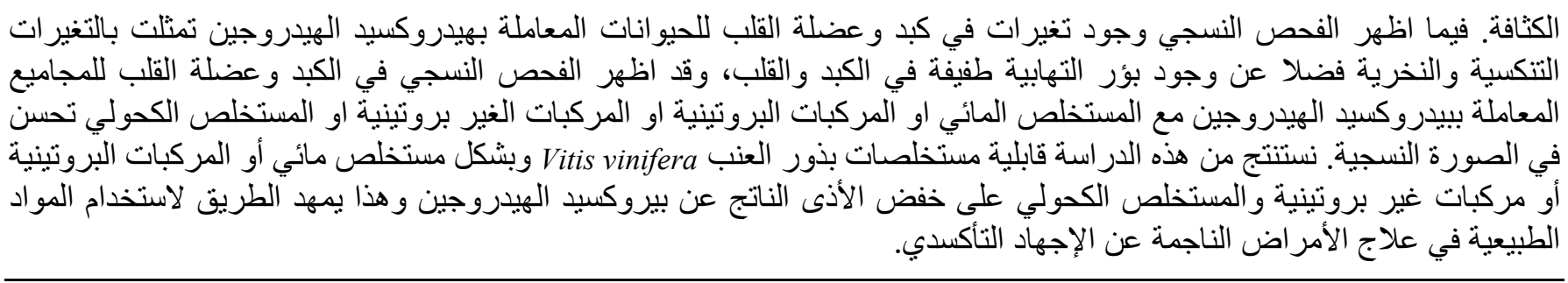

\section{Introduction}

Oxygen is essential for the survival of all on this earth (1). During the process of oxygen utilization in normal physiological and metabolic processes approximately 5\% of oxygen gets univalently reduced to oxygen derived free radicals like superoxide, hydrogen peroxide, hydroxyl and nitric oxide radicals (2). All these radicals known as reactive oxygen species (ROS) exert oxidative stress towards the cell to face about 10000 oxidative hits per second (3). When generation of ROS overtakes the antioxidant defense of the cells, the free radicals start attacking the cell proteins, lipids and carbohydrates and this lead to a number of physiological disorder (4). Free radicals are involved in the development of degenerative diseases (5). They have also been implicated in the pathogenesis of atherosclerosis, diabetes, liver damage, nephrotoxicity, inflammation, cancer, cardiovascular disorders, neurological disorders and in the process of aging (6). Many plants contain substantial amounts of antioxidants including vitamin $\mathrm{C}$ and $\mathrm{E}$, carotenoids, flavonoids and tannins and thus can be utilized to scavenge the excess free radicals (7). Grape seed is a natural plant constituent and contains lipids, proteins, carbohydrates, and polyphenols. Proanthocyanidins which are more powerful antioxidants than other are the most abundant phenolic compounds in grape seeds, and are high-molecular-weight polymers comprised of dimmers or trimers of $(+)$-catechin and $(-)$ epicatechin (8). As well as vitamin $\mathrm{C}$, vitamin $\mathrm{E}$, and gallic acid (9), that has various biological functions such as antibacterial, antiviral, anti-inflammatory, antiallergic, and vasodilatory actions (10).

\section{Material and method}

\section{Preparation of aqueous extract}

Grapes seeds were dried and powdered with a knife mill, The aqueous extract was prepared by freezing and thawing the 250 grams of grapes seeds with liquid nitrogen several times to rupture the cell membrane, a $750 \mathrm{ml}$ of distilled water was added and the crude homogenate was stirred for additional two hours then filtered through several layers of moselin (cheese-cloth). Finally, the mixture was centrifuged at refrigerated centrifuge for 15 minutes at $33520 \mathrm{xg}$. The filtrate extract after reduction its volume to about $1 / 3$ by lyophilization was kept for further investigation (11).

\section{Precipitation of the protein}

The proteinaceous substance was separated from the aqueous extract by cold acetone precipitation technique (12).

\section{Preparation of alcoholic extract}

Grapes seeds were dried and powdered with a knife mill, $30 \mathrm{~g}$ of sample was mixed with $300 \mathrm{ml}$ of $96 \%$ ethanol using a shaking water bath for 24 hour at room temperature. The extract was separated from solid concentrate by filtering through Whatman No. 1 filter paper. The remaining residue was re-extracted twice and the extracts were pooled. The solvent was removed under vacuum at $40 \mathrm{C}^{\circ}$ using a rotary vacuum evaporator (13).

\section{Experimental animals and groups}

Male local rabbits 30 weighting between $800 \pm 50 \mathrm{~g}$ was used. The animals were kept in cages with feed diet and given tap water, and housed in a constant $18-25 \mathrm{C}^{\circ}$ temperature environment with12:12 hour light: dark cycle. Animals were divided into six groups of five rabbits each. Group (GI) received a regular rabbit diet and maintained as a control group ; Group (GII) rabbits subjected to experimentally induced oxidative stress by supply of drinking water containing $0.5 \% \mathrm{H}_{2} \mathrm{O}_{2}$ (14) was prepared daily over entire 30 days period of the experiment after the end of 15 days of $\mathrm{H}_{2} \mathrm{O}_{2}$ treated animals were selected randomly to serve as the crude seeds for 15 days with $\mathrm{H}_{2} \mathrm{O}_{2}$ to complete 30 days. aqueous extract treated group (GIII) animal of this group received extract Grapes seeds. for 15 days. Group (GIV) received proteinous extract of Grapes seeds. for 15 days. Group $(\mathrm{GV})$ received non- proteinous extract of Grapes seeds. for 15 days. Group (GVI) received alcohol extracts of Grapes seeds. for 15 days. The extraction was injected intraperitonl as a single dose 150 $\mathrm{mg} / \mathrm{kg} \mathrm{BW}$ daily. At the end experiment period, rabbits were euthanized, serum and tissue sample were analyzed after collection.

\section{Determination of parameters}

The lipid parameter Total cholesterol, Triglycerides and high density lipoprotein-cholesterol were determined by 
using a standard enzymatic assay (Fortress/UK kit) (15). One gram of heart and liver tissue were removed for estimation of MDA by thiobarbituric acid test as previously described by (16). GSH concentration of heart and liver were measured according to (17). As well as determination of enzymatic antioxidant (Gpx, CAT, SOD) described by (18).

\section{Statistical analyses}

Results were expressed as mean $\pm \mathrm{SD}$, statistical evaluation was done using one-way analysis of variance (ANNOVA) which is followed by Duncan test. The level of statistical significance was set at $\mathrm{P}<0.05$ (19).

\section{Histopathological study}

Following necropsy, liver and heart immediately removed for histopathological study were fixed in $10 \%$ neutral buffered formalin fore 48-72 hours, the samples dehydrated in a series of increasing concentration of ethanol and cleared in xylol then embedded in paraffin and sectioned at 5-6 $\mu \mathrm{m}$ thickness by using a rotary microtome thin stained with hematoxylin and eosin stain. The slides were examined under light microscope (20).

\section{Results}

\section{lipid profile}

Table 1 showed that $0.5 \%$ of $\mathrm{H}_{2} \mathrm{O}_{2}$ in drinking water significantly increase in total cholesterol triglycerides, low density lipoprotein and very low-density lipoprotein, while high density lipoprotein showed decreased significantly compared with untreated control rabbits. In male rabbits subjected to $\mathrm{H}_{2} \mathrm{O}_{2}$ and treated with aqueous, proteinous and non- proteinous and alcoholic extracts, level of lipid profile indicated decrease significantly of Tch, TGs, LDL-c and VLDL-c, while HDL-c increase significantly after treated with aqueous, proteinous and alcoholic extracts as compared with $\mathrm{H}_{2} \mathrm{O}_{2}$ value.

Table 1: level of lipid profile in serum of male rabbit treated with $0.5 \% \mathrm{H}_{2} \mathrm{O}_{2}$ and Grapes seeds extracts

\begin{tabular}{lccccc}
\hline Group & $\begin{array}{c}\text { Tch } \\
(\mathrm{mmol} / \mathrm{L})\end{array}$ & $\begin{array}{c}\text { TGS } \\
(\mathrm{mmol} / \mathrm{L})\end{array}$ & $\begin{array}{c}\text { HDL-c } \\
(\mathrm{mmol} / \mathrm{L})\end{array}$ & $\begin{array}{c}\text { LDL-c } \\
(\mathrm{mmol} / \mathrm{L})\end{array}$ & $\begin{array}{c}\text { VLDL-c } \\
(\mathrm{mmol} / \mathrm{L})\end{array}$ \\
\hline \multirow{2}{*}{ Control } & $4.69 \pm 0.46$ & $1.37 \pm 0.33$ & $1.12 \pm 0.14$ & $3.29 \pm 0.53$ & $0.28 \pm 0.045$ \\
& $\mathrm{c}$ & $\mathrm{d}$ & $\mathrm{b}$ & $\mathrm{c}$ & $\mathrm{c}$ \\
$\mathrm{H}_{2} \mathrm{O}_{2}$ & $5.25 \pm 0.66$ & $2.12 \pm 0.17$ & $1.08 \pm 0.13$ & $3.74 \pm 0.41$ & $0.43 \pm 0.061$ \\
& $\mathrm{a}$ & $\mathrm{a}$ & $\mathrm{c}$ & $\mathrm{a}$ & $\mathrm{a}$ \\
$\mathrm{H}_{2} \mathrm{O}_{2}+$ equeous extract & $4.77 \pm 0.31$ & $1.66 \pm 0.23$ & $1.13 \pm 0.11$ & $3.32 \pm 0.44$ & $0.33 \pm 0.031$ \\
& $\mathrm{bc}$ & $\mathrm{cd}$ & $\mathrm{a}$ & $\mathrm{b}$ & $\mathrm{b}$ \\
$\mathrm{H}_{2} \mathrm{O}_{2}+$ proteinous extract & $4.81 \pm 0.41$ & $1.71 \pm 0.32$ & $1.13 \pm 0.09$ & $3.34 \pm 0.42$ & $0.34 \pm 0.042$ \\
& $\mathrm{~b}$ & $\mathrm{c}$ & $\mathrm{a}$ & $\mathrm{b}$ & $\mathrm{b}$ \\
$\mathrm{H}_{2} \mathrm{O}_{2}+$ Non- proteinous extract & $4.90 \pm 0.39$ & $1.96 \pm 0.43$ & $1.08 \pm 0.12$ & $3.45 \pm 0.29$ & $0.37 \pm 0.038$ \\
& $\mathrm{~b}$ & $\mathrm{ab}$ & $\mathrm{c}$ & $\mathrm{ab}$ & $\mathrm{ab}$ \\
$\mathrm{H}_{2} \mathrm{O}_{2}+$ alcohol extract & $4.72 \pm 0.35$ & $1.48 \pm 0.32$ & $1.14 \pm 0.09$ & $3.29 \pm 0.53$ & $0.29 \pm 0.031$ \\
& $\mathrm{c}$ & $\mathrm{d}$ & $\mathrm{a}$ & $\mathrm{c}$ & $\mathrm{c}$ \\
\hline
\end{tabular}

Values are expressed as means \pm SD of 5 rabbits per group.

Mean with same superscript in the column are significantly different from others $(\mathrm{P}<0.05)$.

\section{Tissue MDA concentration}

Tissue of heart and liver thio barbituric acid reactive substances were significantly increase in animals after 30 days of $\mathrm{H}_{2} \mathrm{O}_{2}$ treatment as compared with control group (Table 2). The greatest decrease in MDA content was seen in heart and liver of animals treated with aqueous extraction and alcoholic extraction also showed reduction in lipid peroxidation product as compared with $\mathrm{H}_{2} \mathrm{O}_{2}$ Value.

\section{Tissue GSH concentration}

Tissue of heart and liver GSH content were significantly after 30 days of $\mathrm{H}_{2} \mathrm{O}_{2}$ treatment. There was significant reduction in animals as compared with control group (Table
2) The greatest increase in GSH content was seen in heart and liver of animals treated with aqueous extraction and alcoholic extraction.

\section{Tissue Gpx, CAT and SOD concentration:}

Table 3 showed that $0.5 \%$ of $\mathrm{H}_{2} \mathrm{O}_{2}$ in drinking water significantly decrease in glutathione peroxdiase, Catalase and superoxide dismutase level in heart and liver compared with control animal group rabbits. In rabbits subjected to $\mathrm{H}_{2} \mathrm{O}_{2}$ and extracts increase significantly $\mathrm{Gpx}$, SOD and CAT level, especially when treated with alcohol extract compared with $\mathrm{H}_{2} \mathrm{O}_{2}$ groups. 
Table 2: Level of malondialdehyde MDA and Glutathione GSH in heart and liver tissues of rabbit treated with $0.5 \% \mathrm{H}_{2} \mathrm{O}_{2}$ and Grapes seeds extracts

\begin{tabular}{|c|c|c|c|c|}
\hline \multirow{2}{*}{ Group } & \multicolumn{2}{|c|}{ GSH (nmol/g) } & \multicolumn{2}{|c|}{ MDA (nmol/g) } \\
\hline & Heart & Liver & Heart & Liver \\
\hline Control & $293 \pm 33$ & $765 \pm 20$ & $2323 \pm 41$ & $2224 \pm 24$ \\
\hline Control & $\mathrm{a}$ & $\mathrm{a}$ & $\mathrm{f}$ & $\mathrm{d}$ \\
\hline$U$ & $244 \pm 24$ & $520 \pm 44$ & $6742 \pm 29$ & $4111 \pm 41$ \\
\hline $\mathrm{H}_{2} \mathrm{O}_{2}$ & $\mathrm{c}$ & c & $\mathrm{a}$ & $\mathrm{a}$ \\
\hline $\mathrm{H}_{2} \mathrm{O}_{2}+$ equeous extract & $\begin{array}{c}273 \pm 23 \\
\mathrm{~b}\end{array}$ & $\begin{array}{c}584 \pm 25 \\
\text { bc }\end{array}$ & $\begin{array}{c}4216 \pm 47 \\
\mathrm{~cd}\end{array}$ & $\begin{array}{c}2511 \pm 48 \\
c\end{array}$ \\
\hline $\mathrm{H}_{2} \mathrm{O}_{2}+$ proteinous extract & $\begin{array}{c}269 \pm 36 \\
b\end{array}$ & $\begin{array}{c}567 \pm 17 \\
\text { bc }\end{array}$ & $\begin{array}{c}4941 \pm 66 \\
\mathrm{c}\end{array}$ & $\begin{array}{c}3461 \pm 51 \\
\mathrm{~b}\end{array}$ \\
\hline $\mathrm{H}_{2} \mathrm{O}_{2}+$ Non- proteinous extract & $\begin{array}{c}250 \pm 28 \\
\mathrm{c}\end{array}$ & $\begin{array}{c}526 \pm 47 \\
\mathrm{c}\end{array}$ & $\begin{array}{c}5625 \pm 51 \\
\mathrm{~b}\end{array}$ & $\begin{array}{c}3351 \pm 33 \\
\mathrm{~b}\end{array}$ \\
\hline $\mathrm{H}_{2} \mathrm{O}_{2}+$ alcohol extract & $\begin{array}{c}312 \pm 25 \\
\mathrm{a} \\
\end{array}$ & $\begin{array}{c}732 \pm 32 \\
\text { a }\end{array}$ & $\begin{array}{c}3321 \pm 47 \\
\mathrm{e}\end{array}$ & $\begin{array}{c}2006 \pm 44 \\
d\end{array}$ \\
\hline
\end{tabular}

Values are expressed as means \pm SD of 5 rabbits per group.

Mean with same superscript in the column are significantly different from others $(\mathrm{P}<0.05)$.

Table 3: Level of glutathione peroxdiase Gpx, Catalase CAT and superoxide dismutase SOD in heart and liver tissues of rabbit treated with $0.5 \% \mathrm{H}_{2} \mathrm{O}_{2}$ and Grapes seeds extracts

\begin{tabular}{lcccccc}
\hline \multirow{2}{*}{ Group } & \multicolumn{2}{c}{ Gpx $(\mathrm{mmol} / \mathrm{L})$} & \multicolumn{2}{c}{ CAT $(\mathrm{mmol} / \mathrm{L})$} & \multicolumn{2}{c}{ SOD $(\mathrm{mmol} / \mathrm{L})$} \\
\cline { 2 - 7 } & $\mathrm{Heart}$ & Liver & Heart & Liver & Heart & Liver \\
\hline \multirow{2}{*}{ control } & $4.40 \pm 0.51$ & $6.80 \pm 0.51$ & $0.156 \pm 0.01$ & $0.170 \pm 0.01$ & $2.00 \pm 0.2$ & $2.30 \pm 0.2$ \\
& $\mathrm{a}$ & $\mathrm{a}$ & $\mathrm{a}$ & $\mathrm{a}$ & $\mathrm{a}$ & $\mathrm{a}$ \\
$\mathrm{H}_{2} \mathrm{O}_{2}$ & $3.0 \pm 0.12$ & $3.43 \pm 0.32$ & $0.109 \pm 0.01$ & $0.09 \pm 0.01$ & $1.03 \pm 0.23$ & $1.23 \pm 0.2$ \\
& $\mathrm{~d}$ & $\mathrm{~d}$ & $\mathrm{~d}$ & $\mathrm{~d}$ & $\mathrm{~d}$ & $\mathrm{e}$ \\
$\mathrm{H}_{2} \mathrm{O}_{2}+$ equeous extract & $3.41 \pm 0.41$ & $4.98 \pm 0.49$ & $0.124 \pm 0.01$ & $0.132 \pm 0.02$ & $1.41 \pm 0.11$ & $1.41 \pm 0.13$ \\
& $\mathrm{~cd}$ & $\mathrm{c}$ & $\mathrm{bc}$ & $\mathrm{c}$ & $\mathrm{c}$ & $\mathrm{d}$ \\
$\mathrm{H}_{2} \mathrm{O}_{2}+$ proteinous extract & $3.60 \pm 0.56$ & $5.43 \pm 0.49$ & $0.111 \pm 0.02$ & $0.139 \pm 0.02$ & $1.46 \pm 0.12$ & $1.56 \pm 0.12$ \\
& $\mathrm{c}$ & $\mathrm{b}$ & $\mathrm{d}$ & $\mathrm{bc}$ & $\mathrm{c}$ & $\mathrm{c}$ \\
$\mathrm{H}_{2} \mathrm{O}_{2}+$ Non- proteinous extract & $3.55 \pm 0.11$ & $4.60 \pm 0.56$ & $0.116 \pm 0.02$ & $0.134 \pm 0.01$ & $1.81 \pm 0.11$ & $1.87 \pm 0.12$ \\
& $\mathrm{c}$ & $\mathrm{cd}$ & $\mathrm{c}$ & $\mathrm{c}$ & $\mathrm{b}$ & $\mathrm{b}$ \\
$\mathrm{H}_{2} \mathrm{O}_{2}+$ alcohol extract & $3.90 \pm 0.12$ & $5.55 \pm 0.42$ & $0.132 \pm 0.02$ & $0.146 \pm 0.02$ & $1.36 \pm 0.15$ & $1.35 \pm 0.13$ \\
& $\mathrm{~b}$ & $\mathrm{~b}$ & $\mathrm{~b}$ & $\mathrm{~b}$ & $\mathrm{c}$ & $\mathrm{d}$ \\
\hline
\end{tabular}

Values are expressed as means \pm SD of 5 rabbits per group.

Mean with same superscript in the column are significantly different from others $(\mathrm{P}<0.05)$.

Histopathological effect of Grapes seeds extracts on histological changes of the liver and heart tissues

Liver

Histopathological examination of the hepatic tissue demonstrated that $\mathrm{H}_{2} \mathrm{O}_{2}$ induces dilatation and congestion in the blood vessel, vacuolar degeneration (Figure 1) and coagulative necrosis of hepatocytes in addition to focal infiltration of inflammatory cells (Figure 2). However, induced only vacuolar degeneration, with dilatation of central vein with few areas of necrosis (Figure 3 ) when co administered with aqueous extracts compared with control group (Figure 4).

\section{Heart}

Histopathological examination of the myocardial muscle demonstrated that $\mathrm{H}_{2} \mathrm{O}_{2}$ induces degeneration of cardiomyocytes and interstitial edema were also seen (Figure 5), in addition to coagulative necrosis with pyknosis of the nucleus of cardiomyocytes, also infiltration of inflammatory cell can see (Figure 6). However, the incidence of necrosis and infiltration of inflammatory cells was decreased in animals treated with $\mathrm{H}_{2} \mathrm{O}_{2}$ and aqueous extracts of normal (Figure 7) and somewhat appearance of cardiac muscle fibers compared with control group (Figure 8). 


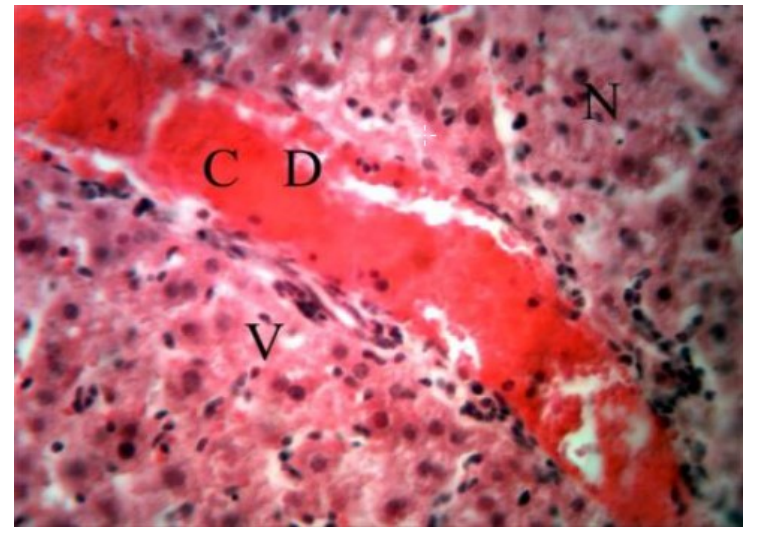

Figure 1: Liver of $0.5 \% \mathrm{H}_{2} \mathrm{O}_{2}$ group showed dilation and congestion of central vein $(\mathrm{D}, \mathrm{C})$, vacuolar degeneration of hepatocytes (V) and coagulative necrosis of the hepatocytes (N). H\&E. 400X.

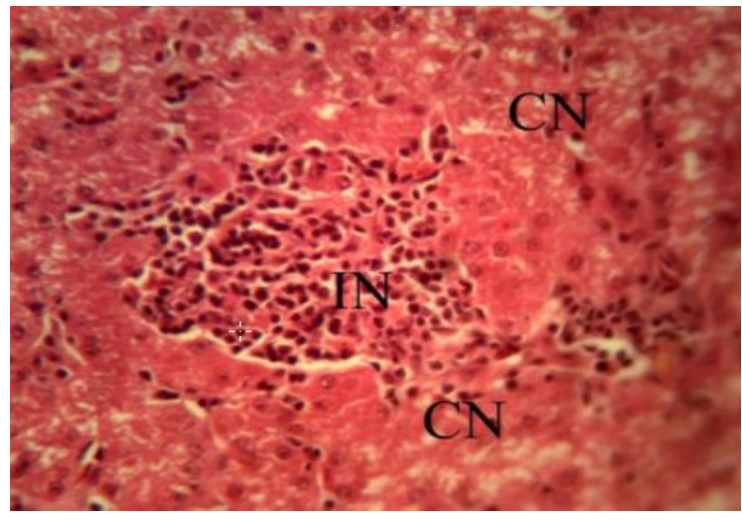

Figure 2: Liver of $0.5 \% \mathrm{H}_{2} \mathrm{O}_{2}$ group showed coagulative necrosis of the hepatocytes $(\mathrm{CN})$ and focal infiltration of inflammatory cells (IN). H\&E. 400X.

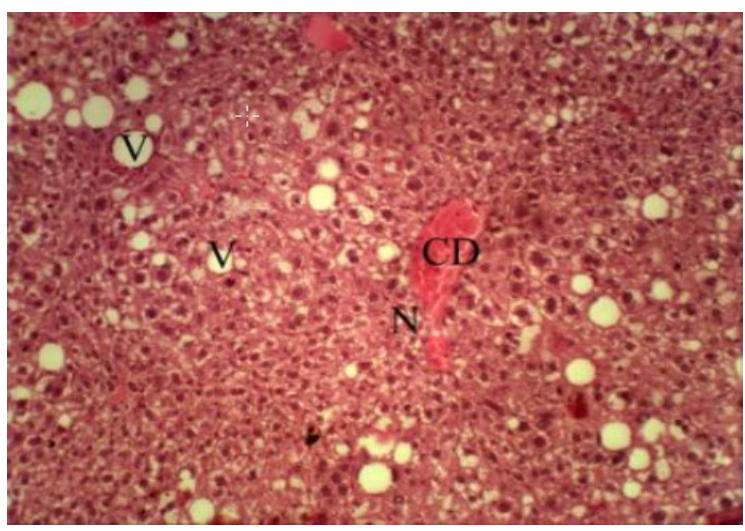

Figure 3: Liver of $0.5 \% \mathrm{H}_{2} \mathrm{O}_{2}$ and treated with aqueous extract showed dilation and congestion of central vein (CD), and coagulative necrosis of the hepatocytes (N), vacuolar degeneration (V). H\&E. 100X.

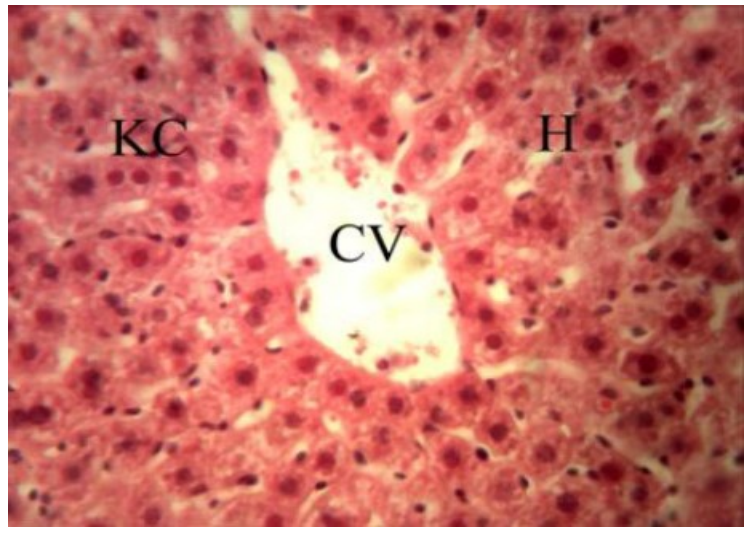

Figure 4: Liver of control group showed central vein (CV), hepatocytes $(\mathrm{H})$ and Kupffer cells (KC). H\&E. 400X.

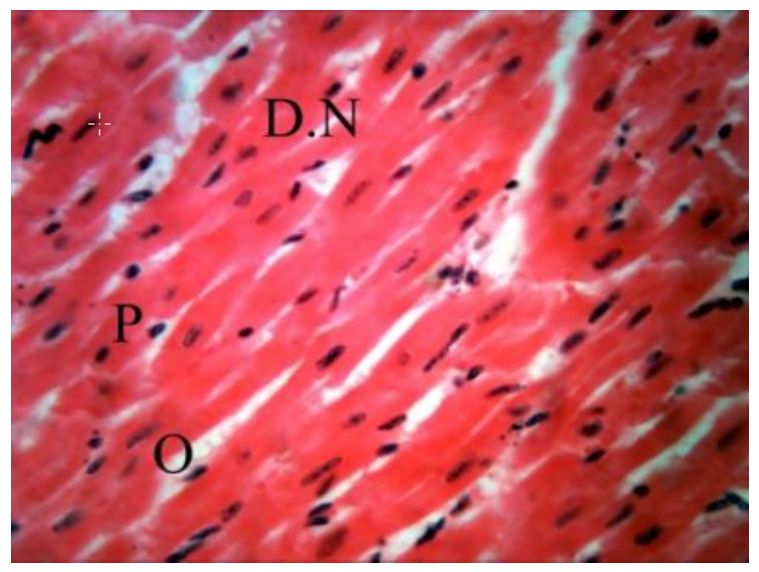

Figure 5: Heart tissue of $0.5 \% \quad \mathrm{H}_{2} \mathrm{O}_{2}$ group showed degeneration and necrosis of cardiomyocytes (D.N), interstitial edema (O) and pyknosis of the nuclei of cardiomyocytes (P). H\&E. 400X.

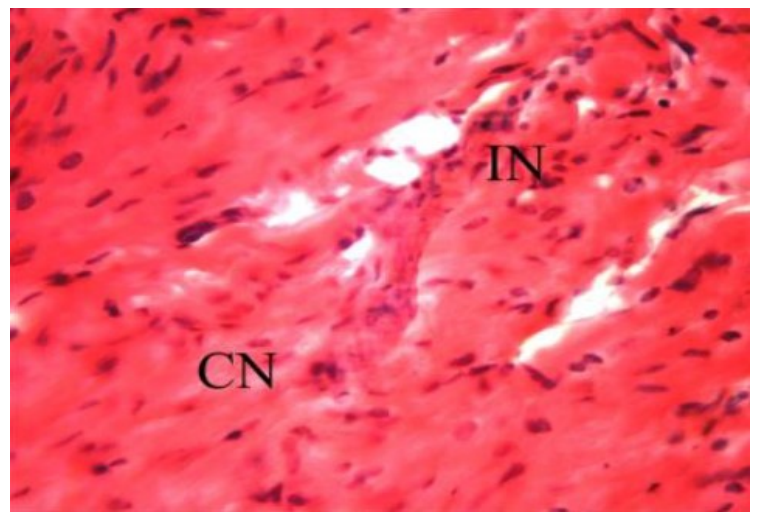

Figure 6: Heart tissue of $0.5 \% \mathrm{H}_{2} \mathrm{O}_{2}$ group infiltration of inflammatory cells (IN), with coagulative necrosis of cardiomyocytes $(\mathrm{CN})$. H\&E. 400X. 


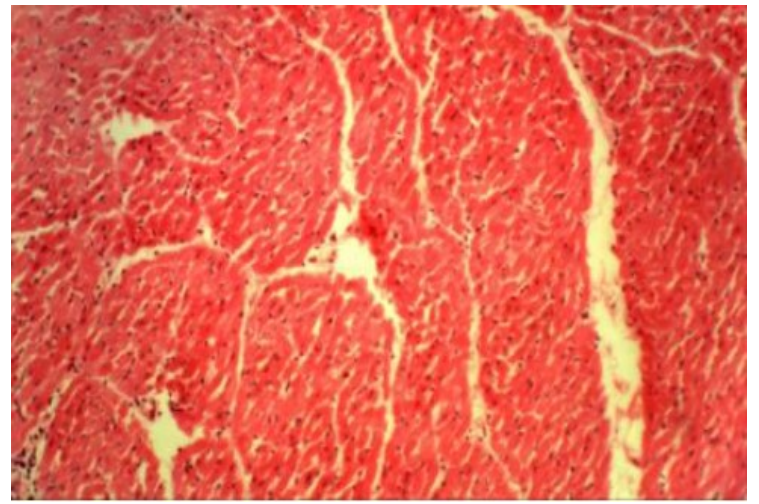

Figure 7: Heart tissue of $0.5 \% \mathrm{H}_{2} \mathrm{O}_{2}$ treated with aqueous extracts showed improvement of histological picture somewhat normal appearance of cardiac muscle fibers. H\&E. 100X.

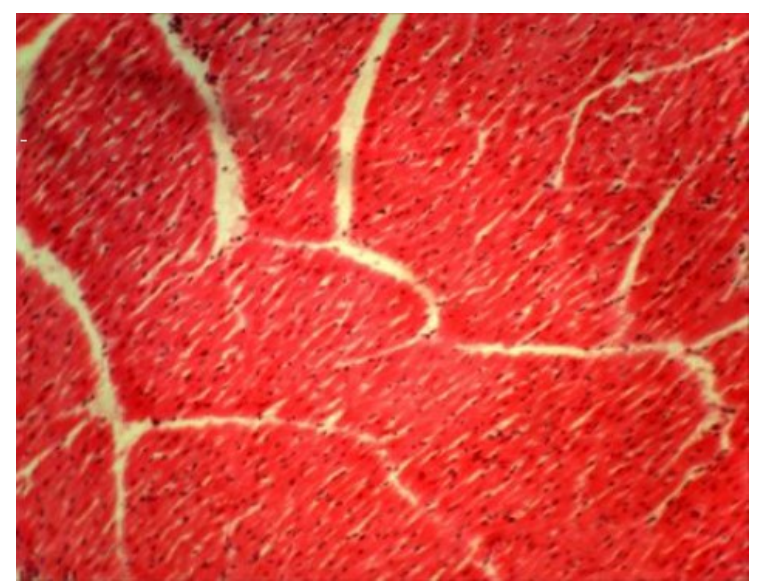

Figure 8: Heart tissue of control group showed welldeveloped of cardiac muscle fiber. H\&E. 100X.

\section{Discussion}

This study illustrated a marked elevation in level of lipid profile (Tch, TGs, LDL-c, VLDL-c). lipid concentration in serum of rabbit treated with $0.5 \% \mathrm{H}_{2} \mathrm{O}_{2}$ for 30 days, suggesting that these changes reflect susceptibly of animal to experimental induce hyperlipidemia and atherosis by oxidative stress that closely resemble those found in human, rat and rabbit (21). This study used to determine the effect of with aqueous, proteinous, non- proteinous and alcohol extracts of Grapes seeds as antioxidant, the importance of Grapes seeds as antioxidant (protective effect) take place via its content of flavonoid, which protect LDL-c from oxidation of the initial stages of lipid peroxidation by acting as free radical scavenger (22). Quercetin and flavonoid were shown to be bind to the surface of LDL particles via the formation of an ether bond
(23). Grapes seeds extraction, all aqueous, proteinous, nonproteinous and alcoholic extracts significantly cause ameliorative effects on lipid perxidation and antioxidant status can decrease in level of Tch, TGs, LDL-c and VLDL-c in addition to, decrease concentration of MDA in the heart and the liver tissues associated with increased level of HDL-c in serum and GSH of heart and liver tissues. Our study suggests that flavonoid and ascorbic acid, important continent seeds of Grapes and play important role in prevention endothelial cell-mediated LDL-c lipid peroxidation (24). However, Grapes seeds extract reduced the tendency of LDL-c oxidize and enhance antioxidant enzyme activity of cells (25). This study revealed that no protection effect of this dose of Grapes seeds aqueous extract was observed at the histopathological levels. Thus, the protective effect of Grapes seeds aqueous extract against $\mathrm{H}_{2} \mathrm{O}_{2}$ induced oxidative stress and atherogenesis may be due to changes in the antioxidant enzyme chain breaking antioxidant activity and have anti proliferating properties and its ability to inhibit redox-sensitive signal transduction pathway related to cell growth on vascular smooth muscle cells (26). In this study, the Grapes seeds extracts treatment inhibit the increase in lipid peroxidation of rabbit as compared with the $\mathrm{H}_{2} \mathrm{O}_{2}$ treated group. Antioxidant defense systems SOD, CAT and GPx activity is significantly decreased in $\mathrm{H}_{2} \mathrm{O}_{2}$ treated rabbits. This result could be due to a feedback inhibition or oxidative inactivation of enzyme protein because of excess ROS generation. The generation of $\alpha$-hydroxyethyl radical may lead to inactivation of these enzymes (24). There was a significant increase in the activity of these enzymes after treatment with Grapes seeds extracts. these extracts may be increases antioxidant action by scavenging ROS, enhancing the cellular antioxidant enzymes and increasing glutathione in the cells.

\section{References}

1. Blokhina O, Virolainen E. Kurt V. Antioxidants, Oxidative Damage and Oxygen Deprivation Stress. Ann Bot. 2003;91(2):179-194. https://doi.org/10.1093/aob/mcf1 18

2. Patel BD, Kamariya YH, Patel MB. Free radical Scavenging Potential of Ethanolic Extract of Uraria pictalinn. Pharmacol on line. 2011;2:134-145.https://pharmacologyonline.silae.it/front/archives

3. Krishan P, Chakkarwar V. Diabetic nephropathy: Aggressive involvement of oxidative stress. J Pharm Educ Res. 2011;2(1):35-41.

4. Cotran RS, Kumar V, Collins T. Robbin's pathological basis of diseases. $8^{\text {th }} .:$ Elsevier; 2009. 723-725 p. https://www.elsevier.com/ books/robbins-and-cotran-pathologic-basis-of-disease-professionaledition/kumar/978-1-4377-0792-2

5. Ashokkumar D, Mazumder UK, Gupta M, Senthilkumar GP, Selvan VT. Evaluation of antioxidant and free radical scavenging activities of Oxystelma esculentum in various in vitro models. J Comp Integ Med. 2008;5(1):1-6. https://doi.org/10.2202/1553-3840.1124

6. Aiyegoro $\mathrm{O}$, Okoh I. Preliminary phytochemical screening and In vitro antioxidant activities of the aqueous extract of Helichrysum longifolium DC. BMC Compl Alter Med. 2010;10(21):2-8. https://doi.org/10.1186/1472-6882-10-21 
7. Hossain MS, Ahmed M, Islam A. Hypolidemic and hepato protective effects of different fractions of methanolic extract of Momordica charantia (LINN.) in alloxan induced diabetic rats. IJPSR. 2011;2(3):601-607.http://dx.doi.org/10.13040/IJPSR.0975-8232

8. Cho M, Heo Y, Park MK, Oh HJ, Park JS, Woo YJ, Ju JH, Park SH, Kim HY, Min JK. Grape seed proanthocyanidin extract (GSPE) attenuates collagen-induced arthritis. Immunol Lett. 2009;124:102110. https://doi.org/10.1016/j.imlet.2009.05.001

9. Ariga T. The antioxidative function, preventive action on disease and utilization of proanthocyanidins. Biofac. 2004;21:197-201. https://doi.org/10.1002/biof.552210140

10. Bagchi D, Bagchi M, Stohs SJ, Das DK, Ray SD, Kuszynski CA, Joshi SS, Pruess HG. Free radicals and grape seed proanthocyanidin extract. importance in human health and disease prevention. Toxicol. 2000;148:187-97.https://doi.org/10.1016/S0300-483X(00)00210-9

11. Al-Chalabi NS. Effect of proteinous compounds from Protulaca olerace L. plant on some biochemical parameters in mice. Med J Babylon.2005;2(2):169-176. http://www.medicalib.com/article.aspx?jirid $=668$

12. Robyt JF, White BJ. Biochemical techniques theory and practice. New York: Cole publishing company; 1987: 268-269 p. https://lib.ugent.be/catalog/rug01:000233389

13. Miri A, Rad JS, Rad MS, Silva JS. Allelopathic activity of medical plant, Cardaria draba (Lepidium draba L.). Ann Biol Res. 2013;4(6):76-79.https://www.researchgate.net/publication/262728451

14. Wohaib SA, Tohala SH, Dewachi, OS. Effect of vitamin E on hydrogen peroxide- induced oxidative stress in rabbits. Iraqi J Vet Sci. 1994;7(2):81-84. https://vetmedmosul.com/

15. Barham D, Trinder P. An improved color reagent for the determination of blood glucose by the oxidase system. Analyst. 1972;97:142-115. https://doi.org/10.1039/an9729700142

16. Uchiyama M, Mihars M. Determination of malondialdehyde precursor in tissues by thiobarbituric acid. Ann Biochem. 1978;86:271-278. https://doi.org/10.1016/0003-2697(78)90342-1.

17. Sedlak J, Lindsay RH. Estimation of total, protein-bound, and non protein sulfhydryl groups in tissue with Ellman's reagent. Analytical biochemistry.1968:25:192-205. https://doi.org/10.1016/0003-
18. Wheeler CR, Salzman JA, Elsayed NM, Omaye ST, Korte DW. Assays for superoxide dismutase, catalase, glutathione peroxidase and glutathione reducatse activity. Anal Biochem. 1990;184:193-9. https://doi.org/10.1016/0003-2697(90)90668-y

19. Steel RG, Torrie JH. Principle procedures of statistics. $2^{\text {nd }}$ ed. New York: Mc Grow-Hill; 1980. 78-80, 107-109, 125-127 p. https://trove.nla.gov.au/work/9171434?q\&sort=holdings + desc\&_=156 4499467234\&versionId $=223761346$

20. Culling CF, Allison RT, Baur WT. Cellular pathology technique. $4^{\text {th }}$ ed. London: Mid-County press; 1985. 215-237p. https://www.elsevier.com/books/cellular-pathologytechnique/culling/978-0-407-72903-2

21. Al-Bajari A. The effect of some extracts isolated from Phaseolus vulgaris and Vigna sinesis fruits in mice exposed to oxidative stress. Al-Taqani, Found Tech Edu. 2008;21(2):264-276. https://www.iasj.net/iasj?func=fulltext\&aId $=39750$

22. Gholamali AJ, Maleki M, Motadayen MH, Sirus S. Effect of fenugreek, onion and garlic on blood glucose and histopathology of pancreas of alloxan-inducced diabetic rats. Indian J Med Sci. 2005;59(2):64-69. https://doi.org/10.4103/0019-5359.13905

23. Kidd PM. Bioavailability and activity of phytosome complexes from botanical polyphenols: The Silymarin, Curcumin, green tea, and grape seed extracts. Alter Med Rev. 2009;14(3):226-246. https://www.ncbi.nlm.nih.gov/pubmed/19803548

24. Pourghassem-Gargari B, Abedini S, Babaei H, Aliasgarzadeh A, Pourabdollahi P. Effect of supplementation with grape seed (Vitis vinifera) extract on antioxidant status and lipid peroxidation in patient with type II diabetes. J Med Plan Res. 2011;5(10):2029-2034. https://academicjournals.org/journal/JMPR/edition/18 May 2011

25. Higashi Y, Noma K, Yoshizumi M, Kihara Y. Endothelial function and oxidative stress in cardiovascular disease. Circ $\mathrm{J}$ Mar. 2009;73(3):411-8. https://doi.org/10.1253/circj.CJ-08-1102

26. Lafay S, Jan C, Nardon K, Lemaire B, Ibarra A, Roller M, Houvenaeghel M, Juhel C, Cara L. Grape extract improves antioxidant status and physical performance in elite male athletes. J Sports Sci Med. 2009;8:468-480. https://www.jssm.org/hf.php?id=jssm-08$\underline{468 . x m l}$ 